\title{
A főhatalomváltás „első felvonása” Érsekújvárban 1918-1919
}

\author{
Bencze Dávid
}

\section{The "first act" of the change of main power in Érsekújvár 1918-1919 Abstract}

The historical event of "Trianon" is the most neuralgic point in the history of the Carpathian Basin. This period (1918-1920) means the disintegration of "Historic Hungary" and the separation of nationalities from Austro-Hungarian Monarchy. The results of the national-aspirations of independence was the establishment of new "nation states" in the Carpathian Basin. Czechoslovakia as a multiethnic nation state was also created in 1918. The professional historians today agree that the Treaty of Trianon has many factors and different precedents. The new minority-communities had a "traumatic experience", because they separated from Hungary and they became citizens of the new states. The paper explains this problem - the empire-changes - as a longer process. The study focuses on the progression of "Trianon" in Czechoslovakia. In the frame of our research we examine a South-Slovakian city - Érsekújvár. The aim of this paper is to present events which happened in the city during the end of 1918 and the beginning of 1919. After the empire-changes, Érsekújvár became an ethnically mixed (Slovakian-Hungarian)city. In my research I use archival sources from the Archive of District Office in Érsekújvár and press materials, more specifically, a regional newspaper Érsekújvár és Vidéke [Érsekújvár and its region] and some state newspapers. I also examine remembrances.

Keywords: Érsekújvár (Nové Zámky); empire-changes; railway strike; resistance; establishment of Czechoslovakia

Kulcsszavak: Érsekújvár; impériumváltás; vasutassztrájk; ellenállás; Csehszlovákia megalakulása

Subject-Affiliation in New CEEOL: History - Recent History - Pre-WW

DOI: $10.36007 /$ eruedu.2020.2.061-077

1 A tanulmány az EFOP-3.6.1-16-2016-00001. számú, „Kutatási kapacitások és szolgáltatások komplex fejlesztése az EKE-n" c. projekt keretében valósult meg. The study was realized in the framework of the project EFOP-3.6.1-16-2016-00001, "The complex improvement of research capacities and services on EKU". 


\section{Bevezető}

Általános jelenség, hogy a szlovákiai magyarok egészéről szóló tudományos igényü munkák száma rendkívül alacsony, ahhoz képest, amennyinek lennie kellene, vagy legalábbis van még a tudománynak tatozása e téren. Ez visszavezethető arra, hogy a regionalitás, a térségekben való gondolkodás nemcsak a múltban, de napjainkban is meghatározó a Felvidéken. Ennek ellenére azonban még azon munkáknak a száma sem elégséges, amelyek egy-egy város vagy régió történetét dolgozzák fel, s ez különösen igaz az 1918-1920 közötti események feltárásának a tekintetében.

Az impériumváltás, vagyis Magyarország felbomlása a magyarság számára olyan traumának számít, mely mind a mai napig komoly hatást gyakorol a közösségi identitás formálódására. Mindezzel együtt kétségtelen, hogy Trianon a magyar nemzeti tragédiáknak a legmarkánsabb pillanatához tartozik. Egyrészt azért, mivel jelentősen sérült az ország területi integritása, s emellett a maradék Magyarország a régióban való vezető szerepét is végképp elveszítette. Eközben azoknak a magyaroknak a sorsa, akik az impériumváltást követően váltak az anyaországból újonnan létrejött államok kisebbségeivé, rendkívül összetetté vált. A helyzetet tovább bonyolítja, hogy a döntést egy olyan nemzetközi tanácskozás hozta, amely nem törekedett a kompromisszumos megoldásra Magyarország és az újonnan alakuló nemzetállamok között.

Mint tudjuk, a Monarchia nemzetiségi összetételét figyelembe véve a többségi nemzetet jelentő magyarság és a nemzeti kisebbséghez tartozók között olyan feszült helyzet alakult ki, amely az elhúzódó, vesztes háború kapcsán csak tovább fokozódott (Jászi 1982). Az elveszített első világháború pedig a történelmi Magyarország felbomlásához vezetett. Tehát megállapíthatjuk, hogy az impériumváltás gyakorlatilag az elveszitett világháborúval és a nemzetiségek önállósodási törekvéseivel kezdődött el, így az egészet egy folyamatként kell kezelnünk, amelynek meghatározó kezdőpontja a nemzeti tanácsok megalakulása volt (Romsics 2001; Zeidler 2003). A folyamat soron következő „,állomása” Szlovákia déli részének csehek általi - birtokbavétele. A „csúcspontja” - ha ezt lehet így nevezni - pedig, amikor a magyarok által lakott területeken a szlovákiai magyar politika elkezdi a szárnyait bontogatni, és megalakulnak az első magyar pártok Csehszlovákiában. Ezt azért is tekinthetjük „,csúcspontnak”, mivel a politikai elit az 1919-es év második felében felismerte annak fontosságát, hogy a kisebbségben rekedt magyarság érdekképviselete elengedhetetlen egyrészt a béketárgyalások lezárásáig, másrészt pedig a csehszlovák politika térhódításának az ellensúlyozása tekintetében. A békediktátum aláirását, illetve a szerződés ratifikálását pedig a folyamat záróakkordjaként értelmezhetjük.

Mint ismeretes, az első Csehszlovák Köztársaságot a demokrácia és a népek önrendelkezési jogának megtestesitőjeként szokták emlegetni. Már a világháború alatt ezeket az elveket hirdették a csehszlovák emigráció képviselői. Vagyis, hogy a majdani új államalakulat nem fogja a korábbi német és magyar politika kisebbségekkel szembeni gyakorlatát folytatni, s minden nemzetiség az önrendelkezés útjára léphet. Az impériumváltás után nagy súlyt helyeztek rá, hogy az önrendelke- 
zés feltételei a mindennapok gyakorlatában is a törvényes keretek között tünjenek fel, gondoljunk csak a cseh történelmi államjogra való hivatkozásokra. Viszont az a gyakorlat, is jellemzö volt, hogy a kisebbségekre vonatkozó törvények csekély számúak legyenek, és hogy „csupán” a polgári jogaik védelmében részesüljenek. Ezért találkozhatunk a csehszlovák föhatalom oldaláról számos olyan esettel, amikor nem ment bele konfrontálódásba a sérelmeket felsorakoztató kisebbséggel szemben. Így a magyar kisebbség önrendelkezése a gyakorlatban nem valósult meg. Sőt, a föhatalom az elejétöl kezdve következetesen törekedett arra, hogy az ország csehszlovák nemzeti jellegét minél nagyobb térben bontakoztassa ki, s a kisebbség által lakott területeken a kisebbségi jelleg háttérbe szoritására, annak politikai, társadalmi, kulturális, gazdasági és számbeli erejének és súlyának minden eszközzel való csökkentésére törekedtek (Popély 1990, 2010, 2014).

A csehszlovák uralom alá került magyarságnak kezdettöl fogva kemény és kitartó harcot kellett vívnia nemzeti és kollektív jogaiért. Szlovákia teljhatalmú minisztere, illetve annak bürokratikus apparátusa mindjárt a cseh megszállást követő időkben megkezdte a számára nemkívánatos magyar elemek kiküszöbölését (Ablonczy 2018). Sorozatban szüntette meg vagy változtatta (cseh)szlovákká a magyar iskolákat, s ahol ezt nem tudta elérni, ott megnehezítette működésüket (Popély 1991, 1995). A földreform intézkedéseinek köszönhetően pedig igyekezett felhígítani a többségében magyarok által lakott déli területeket. Egyébként általában véve is több eröfeszitést fejtettek ki annak érdekében, hogy a szlovák országrész minél inkább elveszitse magyar jellegét, gondoljunk csak a szimbolikus térhódításra és a magyar intézmények és egyesületek müködésének a betiltására, felfüggesztésére, valamint azon az esetek kiküszöbölésére, amelyekre ráfogható volt az irredentizmus vádja (pl. magyar nemzeti ünnepek megtartása) (Michela 2009).

A magyar közösség fontos rétegét, a magyar értelmiséget, a korábbi politikai elit egy bizonyos hányadát, valamint a gazdasági elit jelentős részét és az társadalom középrétegét meghatározó állami alkalmazottak nagyobb arányát 1919-1920 között rendkívül nehéz helyzetbe hozták, illetve a korábbi meghatározó befolyását igyekezték ellehetetleníteni. Persze a presztízsvesztés nem hozta magával a teljes lefejezés tényét, viszont minden tekintetben már az államtól független pozíciókban kellett folytatniuk müködésüket. Ennek a gyakorlatnak három megnyilvánulási módjáról tudunk. Egyrészt arról beszélhetünk, hogy a politikai elit és az értelmiség egy része már a terület csehek általi birtokbavétele során kényszerből elhagyta a térséget. Itt föleg azokra kell gondolni, akik kiűzetésre kerültek, illetve önként vándoroltak ki. Másfelöl a hüségeskü feltételéhez kötött munkavállalás megtagadása miatt nagyon sok értelmiségi és állami alkalmazott vált munkanélkülivé vagy éppen annak bekövetkezte miatt deklasszálódott. Annak megtagadása miatt váltak az elején munkanélkülivé, majd később valamilyen fizikai munkássá tanárok, tudósok, müvészek stb. Az elit befolyása megnyirbálásának a harmadik módja föleg az anyagilag befolyásos elitet érintette. Itt föképp azokra a vagyonos gazdákra kell gondolnunk, akikre a földreform kerettörvényéhez tartozó 1919. április 16-án elfogadott ún. „elkobzási törvény" vonatkozott, illetve azokra, akik a pénzreform előnytelen átváltása miatt veszítették el társadalmi pozícióikat (Popély 2010; Ölvedy 1926; Bárdi - Fedinec - Szarka 2008). 
Mivel Trianon és az impériumváltás folyamata nemcsak az elcsatolt területek arculatát alakította át, hanem a közösségi identitás meghatározásában, a magyar kollektív emlékezetben is mély nyomokat hagyott, így a témát nagyobb perspektívából vizsgáló szakirodalom jellemzően és érzékelhetően sokoldalú és sokszinü. E munka alapvetően csak reflexiót jelent a nagyperspektívában megközelített szakirodalomra, s inkább kiván foglalkozni a helyi, konkrétabban az érsekújvári történésekkel. Emellett azt is fontosnak tartom újra kiemelni, hogy csupán néhány helytörténeti mü született eddig, amelyek regionális szinten tárgyalták a korszak eseményeit. Ezek jelentős része inkább ismeretterjesztés szándékával született meg, így ezeket erős kritikával kell kezelni. Másfelöl rengeteg olyan tematikus írás született, amely egy-egy történelmi jelenséggel foglalkozik a szlovákiai magyarság száz évét illetően, viszont ritkán tárgyalja az érsekújvári régióra vonatkozó következtetéseket (Angyal 2002; Bukovszky 2005; Deák 1995; Houdek 1931; Hronský1987; Zdeněk 1928; Romsics 2017, 2001; Szekfü 1920).

A tanulmány tehát az egykori Magyarország kiválasztott régiójában - Érsekújváron és környékén - a föhatalom átmenetének a bemutatását vállalja fel, s azon belül is a csehszlovák berendezkedés első felvonását, vagyis a cseh légiók megjelenéséig vállalkozik az események tárgyalására. Levéltári elemzésekből kiderült, hogy az 1918. év végi és 1919. év eleji önkormányzat által adott intézkedések fő céljai a Károlyi-féle pacifizmus szellemiségében születtek meg, és a helyi közbiztonság fenntartásának megteremtésére irányultak. Ennek okán külön fejezetben szeretném megvizsgálni, hogy milyen összefüggések voltak a helyi önkormányzatokhoz érkezett utasítások és az arra adott reakciók, valamint a folyamatos cseh birtokbavétel híre között. Így például az impériumváltás folyamata mennyire befolyásolta a magyar államhoz tett hüségesküvel rendelkező hivatalnokok és a helyi képviselök elmenekülését a térségböl.

A levéltári kutatás egyik érdekes kérdéseként fogalmazódott meg bennem, hogy vajon a Tanácsköztársaság vörös hadseregének a megjelenése milyen mértékben járulhatott hozzá a kisebbségi keretek közé került magyarság Csehszlovák Köztársaság elleni tüntetéseihez. Meglepő, hogy az északi hadjárat ideologikus mivolta miatt a környék szlovák nemzetiségü többséggel rendelkező településein (például Tótmegyeren - Palárikovo), vagy az Érsekújvárban állomásozó cseh nemzetiségü katonák egy része üdvözölte a hadsereg katonáit. Az is érdekes lehet, hogy bizony voltak olyan magyar többségű települések, ahol a lakosság a nemtetszését fejezte ki, s a hadsereg megjelenésében újabb potenciális veszélyhelyzetet érzékelt. Így amíg a cseh légiókban a rendfenntartás öreit látták, addig a magyar hadseregben a rend felforgatóit vélték felfedezni.

\section{A kisebbségi helyzet kialakulása}

A Csehszlovákiába került magyarság tényleges számát nem lehet hitelt érdemlő módon pontosan megállapítani, mivel a népszámlálások általában tízévenként kerülnek megszervezésre, ezért a szlovákiai magyarság demográfiai adatainak a hitelességét, illetve azok jellemzőit csupán korlátozott érvénnyel ismerhetjük meg. A 
vizsgált korszakunkra vonatkozóan az 1910-es magyarországi, az 1919-es csehszlovák rendkívüli és az 1921-es tervezett népszámlálást tudjuk felhasználni. Az impériumváltás előtt, a „,boldog békeidőkben”, a prosperitás időszakában a Monarchia gazdagsági fejlődésével összefonódott Felvidéknek nevezett térsége vegyesen lakott területnek számított. Az adatok tanulsága szerint azonban itt is, akárcsak a történelmi magyar állam területén máshol is, elörehaladott állapotban volt a magyarság javára történő asszimiláció. Az 1910-es évi népszámlálás adatai szerint a mai értelemben vett Szlovákia területén összesen 2916086 lakos élt. Az itt élö népesség megoszlása az anyanyelv szerint: 57,9\% szlovák (1 687800 fö); 30,2\% magyar (880 851 fö); továbbá 6,73\% német (198 461 fö); 3,3\% rutén (97 037 fö); a lengyel, cseh, szerb, horvát, román kisebbség az 1\%-ot sem érte el. ${ }^{2} \mathrm{Az} 1910$. évi népszámlálás a későbbi Szlovákiának és Kárpátaljának megfeleltethető területen összesen 818 magyar jellegü községet mutatott ki, amelyböl 671 községben $80 \%$ felett volt a magyarok száma, 76 községet magyar többségünek tekinthetünk, vagyis a magyarok lélekszáma $50-80 \%$ között mozgott, és a maradék 71 község idegen többségünek számított (Turczel 2007, 9).

A magyar ajkú lakosság számára a beilleszkedés rendkívül nehézkesnek bizonyult. Az 1918-1920-ban lezajlott államfordulat következtében számukra új, s számos szempontból idegen társadalmi, politikai viszonyok közé kényszerülve nemzeti kisebbségi státuszba kerültek. Mindez kimutatható a nemzetiségek számarányának változásaiban is. Az 1910-es népszámlálás adatai még azt mutatták, hogy a Szlovákia területén élő magyarság száma 884 ezer fő volt. Ez százalékban valamivel több mint 30\%-ot jelentett a terület összlakosságához képest. 1919 nyarán szerveztek egy újabb népösszeírást, amelynek az volt a célja, hogy felmérje a frissen megalakult ország tényleges összetételét. Az eredmény szerint a területen élő magyarság lélekszáma 689 ezerre csökkent, amely százalékos arányban 23,6\%-ot jelentett. A cseh és a szlovák historiográfia ezt a fajta csökkenést az 1910-es népszámlálás hitelességének a megkérdőjelezésével magyarázza. Ekkora csökkenést azonban nem lehet ilyen egyszerüen magyarázni. Simon Attila úgy véli, hogy alapvetően több tényező okozza a nagy különbséget. Az első tényező a menekültáradat nagysága, a második a több identitással rendelkező városi lakosság identitásváltása. Szintén tényező a magyarság természetes szaporulatának az összlakossághoz viszonyított negatív mutatói, valamint a későbbi asszimiláció is. Mindezek mellett a népszámlálás metodikájában való változás is okozhatja a csökkenés mértékének a nagyságát (Simon 2010, 11-13). A Vavro Šrobár által vezetett Szlovákiai Teljhatalmú Minisztérium az 1919-es összeírást végző biztosok számára kiadott egy gyakorlati útmutatót, amely 50 paragrafusba sürítve foglalta össze a szükséges tudnivalókat a számlálás általános elveivel, a kibocsátott összeírási ívek egyes rovatainak kitöltésével, illetve az adatok összegzésével és statisztikai feldolgozásával kapcsolatban. Az útmutató (Podrobné Poučenie pre popisujúcich poverenkov) 31. paragrafusa tartalmazta a nemzetiség felvételezésével kapcsolatos alapelveket és gyakorlati utasitásokat. Eszerint a nemzetiség alatt a felnőtt (14 évesnél idősebb) és szellemileg egészséges személyeknél az egyén nemzetpolitikai meggyőződése értendő,

2 Sčitání lidu v republike Československé ze dne 15. února 1921. I. Československá statistika - Svazek 9. Praha, 1924,75 . 
amely egy bizonyos nemzeti közösséghez vagy nemzethez való faji hovatartozáson alapszik. Emellett hozzátették, hogy mindenkinek csakis egy nemzetisége lehet. Ennek meghatározásánál egyedül a megszámlált személy akaratának a megnyilvánulása a döntő, s annak adatát feltétlenül hitelesnek kell tekinteni, feltéve persze, ha nem bizonyosodik be, hogy ezt a bevallást más személy által kényszerítve tette (Mráz 1920). Mindez azt jelenthette, hogy a nemzetiségi kérdés nagyobb hangsúlyt kapott, mint az anyanyelv. Így például a zsidóságnak a magyar nemzetiségtől való disszimilációja is megtörténhetett. A zsidóságnak a magyar nemzettestből való nagyarányú formális kiválását az első hivatalos, vagyis az 1921-es népszámlálás indította meg, ugyanis a zsidó vallású személyeknek lehetővé tették, hogy zsidó nemzetiségként definiálják magukat (Turczel 2007, 12-13).

Az 1921-ben megtartott első hivatalos népszámlálás során 634827 fö, vagyis Szlovákia lakosságának 21,48\%-a vallotta magát magyarnak, az 1930-as népszámlálás idején pedig még tovább csökkent a szlovákiai magyarok száma, amely 571988 föt, vagyis az összlakosság 17,58\%-át tette ki (Simon 2010, 12). Ezeket a nagyarányú és rohamos számbeli csökkenéseket előidéző fenti körülményeken kívül még számos olyan ok generálta, amely a magyar kisebbség nemzeti erejét és ellenállási képességét folyamatosan gyengítette. Turczel Lajos szerint „,a kisebbségi elnyomottságból államalkotó nemzetté vált cseh és szlovák népben a visszavágás szelleme élénken élt, és azt az iskola és a közvéleményformáló erők továbbra is ébren tartották. A magyarellenes elfogultságot a Horthy-féle Magyarország revizionizmusa és a csehszlovákiai magyar ellenzéki pártok irredentizmusa még intenzivebbé tette." (Turczel 2007, 14) Természetesen Turczel ezen kijelentése elég tendenciózus és túlzó, de mindenesetre lehetett némi alapja. Ami sokkal nagyobb szerepet játszott a szlovákiai magyarok közösségi megszerveződésének a gyengítésében, az nem más volt, mint a régi közhivatalnoki rétegnek a Magyarországra való önálló távozása, valamint az itt maradtak zömének az állampolgárság rendezhetetlensége után történő kiutasitása. Ölvedi János szerint 101977 személyt utasítottak ki Szlovákia és Kárpátalja területéröl. Az itteni hivatalnoki rétegről pedig megállapítja, hogy „a nép problémáival szemben érzéketlen maradt, és kasztszellemmé fajult nagyfokú exkluzivitása a fordulatig nem csökkent" (Ölvedi 1926, 1).

A középosztály kiesésének a gondját abban állapithatjuk meg, hogy nemcsak lélekbeli hiányt jelentett a szlovákiai magyarok arányában, hanem ennek a kiesett rétegnek a kultúrahordozó és kultúrafogyasztó jellege nagymértékben befolyásolta a szlovákiai magyarság megszerveződésének a kérdését a két háború közötti időszakban.

Popély Gyula a népszámlálás során felmutatott adatok mellett a szlovákiai magyarság területi elhelyezkedésében is látja a közösségi megszerveződés hátrányának az okát. Ugyanis a szlovákiai magyarok által lakott terület pántlikaszerüen mindenütt szorosan a csehszlovák-magyar országhatár mentén húzódott. A magyar etnikum ilyen alakú elhelyezkedése az új államban hátrányos volt abból a szempontból, hogy annak nyugati és keleti végei rendkívül messze voltak egymástól, emellett pedig szinte semmilyen kötődése nem volt egymáshoz, sőt nyilvánvalóan kulturális, mentalitásbeli és világnézeti különbségek mutathatók ki az egyes régiók között (Popély 1995, 10). 
Simon Attila szerint a magyarság csökkenése a statisztikákhoz képest a valóságban nem volt olyan mértékű, mint ahogyan azt a számok jelzik. A városokból némileg ugyan kiszorult a magyarság, de Érsekújvárban, Léván, Rozsnyón, Rimaszombatban, Losoncon továbbra is a magyar nyelvü lakosság számított dominánsnak. A városok kulturális jellegükben, valamint a köztereken használt nyelvet tekintve inkább magyar nyelvvel bírtak (Simon 2010, 22). A magyarság presztízsvesztésének az okát Simon Attila abban látja, hogy a magyar kisebbség többnyire falun élt, így a cseh protekcionista iparpolitika és a protekcionista földbirtokreform a kisebbség előnytelen bevonását okozta. Az előnytelen iparpolitika okán tovább nőtt gazdasági lemaradása a szlovákiai magyarok által lakott régiónak, nemcsak a cseh- és morvaországi, hanem a szlovákiai területekhez képest is. A földbirtokreform kapcsán pedig a korábban e területre jellemzően túlnyomóan nagybirtokokból állt, s ennél fogva pedig viszonylag alacsony volt az önálló gazdálkodók és magas földtulajdonnal nem rendelkező mezőgazdasági munkások száma, mivel a csehszlovák 1919-es földbirtokreform a visszavágás szellemében protekcionista és nacionalista szempontból lett végrehajtva. Az 1919-ben bekövetkezett, Alois Rašín nevéhez füződő pénzreform aránytalanul váltotta át a csehszlovák koronára, így a szlovákiai magyarok jelentős része elszegényedett (Simon 2010, 23-30).

\section{Az impériumváltás statisztikai következményei Érsekújvárban és vidékén tömören}

Mint ahogyan sejteni lehet, Érsekújvár hasonló nemzetiségi változásokon ment keresztül, mint a szlovákiai magyarság egésze. A 1910-es népszámlálási adatok alapján a város szinte teljesen magyar nemzetiségü volt. Kicsivel több mint 16 ezer föt számláló város 91,1\%-a magyar anyanyelvünek vallotta magát. Mellettük a szlovákok, a csehek és a németek együtt alig tették ki az ezer föt. ${ }^{3}$ 1919-es rendkivüli népszámláláson a város lakosságának a száma 19998 fő volt, amelyből a magyarok lélekszáma 12881 föt (64,5\%) tett ki. Mellettük a szlovákok száma 6861 fö (34,5\%) volt. 1921-re már a 19024 föböl 9437 (49,6\%) vallotta magát magyarnak és 7857 (41,3\%) pedig csehszlováknak. Ezekböl megállapítható, hogy a két világháború közötti időszakra a homogenizált városból teljesen kétnyelvű város lett, ahol a két nemzet aránya nagyjából kiegyenlített jelleget mutatott. ${ }^{4}$

Az érsekújvári vonzáskörzetben lévő települések közül Tardoskedden az 1910-es népszámlálás alapján 5353 lakosából 5050 fö, vagyis majdnem az egész település magyar anyanyelvvel bírt, a szlovákság száma 234 föt tett ki. ${ }^{5}$ A 1919 -es rendkívüli népösszeíráson a község lakosainak a száma elérte a 6137 föt, amelyböl 5578 magyar és 551 csehszlovák volt. ${ }^{6}$ A két évvel későbbi népszámlálási adatok azt mutatják, hogy az összlakosság 5815 före csökkent, amelyből 5025 magyar nemzetiségü volt. A szlovákok száma ekkor 698 főt számlált. ${ }^{7}$ A statisztikai számokból

3 Szlovákiai Magyar Adatbank. Településtár: http://telepulesek.adatbank.sk/

4 Seznam miest na Slovensku podla popisu l'udu z roku 1919. Bratislava, 1919.

5 A magyar szent korona országainak népszámlálása. Budapest, 1912.

6 Seznam miest na Slovensku podl'a popisu l'udu z roku 1919. Bratislava, 1919.

7 Sčítání lidu v republice Československé ze dne 15. února 1921. I. Státni úřad statistický, Praha, 1924. 
kiderült, hogy a népesség összetétele tíz év alatt nem változott jelentősebb mértékben. Viszont az 1930-ban tartott népszámlálás során az adatok a következőket mutatják: 6208 lakosából 4683 magyar és 1410 csehszlovák volt. ${ }^{8}$ A számok alapján megállapítható, hogy Tardoskedd község esetében a békediktátum aláírását követő tíz évben megindult egy folyamat, amely a magyarság csökkenését és a magukat csehszlovák nemzetiségünek vallók radikális növekedését okozta. Elképzelhetö, hogy ez egyfajta asszimiláció eredménye, de az sem lehet kizárandó ok, hogy bizonyos körülmények hatására a falu lakosságának egy része csehszlováknak kezdi vallani magát.

Nagysurány esetében az 1910-ben lezajlott népösszeírás alkalmával a város 5225 lakosából 3413 fő szlováknak, 1626 fő magyarnak és 176 németnek vallotta magát. ${ }^{9} \mathrm{Az}$ arány később csak tovább növekedett. Az 1921-es népszámláláskor 6200 lakos élt a városban, amelyböl 4714 személy vallotta magát szlováknak, s mindössze 887 fö magyarnak. A szlovák és a magyar lakosság mellett 451 zsidó vallású és 106 német nemzetiségü vallotta be nemzetiségi hovatartozását. ${ }^{10}$

Tótmegyeren a statisztikák tükrében a magyarság fokozatos kiszorulását figyelhetjük meg. Amíg 1910-ben a 3603 föböl álló településen a magyarok száma még 956 föből állt, 1921-re még csak arányaiban veszít nagyságrendjéböl (932 magyar, 2855 szlovák), 1930-ra viszont a település nemzetiségi összetételét tekintve a magyarság lélekszáma nagymértékben csökkent: 262 magyar, 4084 szlovák.

Komjáton 1910-ben a 4103 fös településen 3186 szlovák és 697 magyar volt. Az 1921-es népszámlálási adatok szerint a település lakossága 300 fövel emelkedett, Az összlakosságból 4254 szlovák és csupán 149 ember vallotta magát magyarnak. Az 1930-as népszámlálási adatok szerint már alig élt ebben a községben magyar ajkú lakos (mindösszesen 44 fö). ${ }^{11}$

Udvardon és Naszvadon fordított volt a helyzet Tótmegyerhez és Komijáthoz képest. Amíg Udvardon az 1910-es népszámlálás során 4377 lakost találtak, ebböl 4343 magyar s mindössze 34 szlovák nemzetiségü személy volt, addig Naszvadon 4304 föből 4179 volt magyar és 125 szlovák. Az 1921-es népszámláláson mindkét településen nőtt a lélekszám, illetve a szlovák lakosok száma is. A statisztikai adatok alapján Udvardon 4867 személy élt, ebböl 4509 magyar, 160 szlovák, 88 roma volt. Naszvadon ebben az évben pedig 4364-en vallották magukat magyarnak, s a csehszlovákok száma 139 föt tett ki. Mindkét településen 1930-ra nagy növekedésnek indul a csehszlovák kisebbség száma. Amíg Udvardon a magyar nemzetiségűek 4536 főt tudtak kimutatni, a szlovákok száma az 1921-es népszámláláshoz képest már 510 före emelkedett. Naszvadon pedig a magyar és a csehszlovák nemzetiségüek aránya 4628 fö a 379-hez. ${ }^{12}$

Felvetődik a kérdés, hogy mi eredményezte a magyarság nagyarányú csökkenését, illetve miért emelkedett folyamatosan a csehszlovákok száma a vizsgált térség-

8 Sčitání lidu v republice Československé ze dne 1. prosince 1930. Státni úrad statistický, Praha, 1934.

9 A magyar szent korona országainak népszámlálása. Budapest, 1912.

10 Sčitání lidu v republice Československé ze dne 15. února 1921. I. Státni úřad statistický, Praha 1924.

11 Szlovákiai Magyar Adatbank. Településtár: http://telepulesek.adatbank.sk/ 12 Szlovákiai Magyar Adatbank. Településtár: http://telepulesek.adatbank.sk/ 
ben. Egyfelöl minden bizonnyal érvényesültek azok a tendenciák, amelyek országosan is okozták a szlovákiai magyarok fogyását. Tehát az 1910-es népszámláláshoz képest az 1921-re vonatkozóan valóban beszélhetünk a lakosság egy részének az identitásváltásáról és a zsidóság formai kiválásáról a magyar nemzettömbből, vagy például Érsekújvár esetében arról, hogy a dolgozó hivatalnokok egy része elhagyta az országot. 1930-ra pedig valószinüsithetjük, hogy az asszimiláció is megtette hatását (Simon 2010, 11-18). A felvidéki magyarság jelentős népességcsökkenése azonban nemcsak az országos átlagot jóval meghaladó mortalitással, de az alacsonyabb népszaporulattal is magyarázható. Ma az asszimiláció számlájára írják a szlovákiai magyarság nagyarányú csökkenését, azonban a témánk idöbeni keretei miatt erről a tényezöröl még nem beszélhetünk. A tudatos identitásváltás módjáról viszont sokkal inkább. Ezért ebbe a kategóriába föleg azok a több nyelven bíró városi középrétegböl származó személyek tartozhatnak, akik a dualizmus korának népszámlálásai során származástól függetlenül inkább magyarnak vallották magukat s magyarként kapcsolódtak be a közéletbe. Identitásuk azonban ennek ellenére nem volt véglegesen rögzülve, csupán az aktuális hatalom „magyarsága” miatt vallották magukat magyarnak. Az 1918-1919-es államfordulatot követően a csehszlovák nemzeti diktatúra és propaganda hatására ez a réteg identitást válthatott, $s$ az 1921-es népszámlálás során már csehszlovák nemzetiségünek vallotta magát. Mindamellett úgy érzem, hogy továbbgondolásra szorul annak az értékelése, hogy a magyarság statisztikai fogyásában mennyire játszottak szerepet más, további tényezők, hogy a helyi lakosság a népszámláláskor csehszlováknak vallja magát. Egyáltalán felmerülhet-e az a kérdés, hogy pusztán gazdasági érdekek okán felveszik vagy elfogadják a csehszlovák állampolgárságot, s ezáltal affiliálódanak a csehszlovák nemzetiséghez. Az 1920-as években rengeteg elutasító kérvény íródott a város magyar vezetéséhez az iparengedélyek kiadatása kapcsán. A magyar jogszabályokkal szemben azonban a Tejhatalmú Minisztérium csak egy feltételhez kötötte az iparengedélyek kiadatását, vagyis azt kérte a kérvényezötöl, hogy vallja magát csehszlováknak. Annak kimutatása, hogy az affiliáció Érsekújvárban mennyire játszott szerepet a magyarok identitásváltásában, még hátravan.

\section{Érsekújvár a két ország mezsgyéjén}

„A háború elvesztése végleg felbontotta a társadalmi egyensúlyt. Forradalom rázta meg a nemzetet, s államát. Négyéves világháború lelki és anyagi pusztítása után, a vesztett háború erkölcsi sokkja után, a forradalom hisztériájával terhelve, emberi és nemzeti erkölcsében meggyalázva szakadt el a Csehszlovákiába került magyarság a nemzettöl s a nemzet államától."13 Ilyen megállapításokkal kezd $A$ felvidéki magyarság húsz éve címủ munka, amelynek az elöszava így kivánta összefoglalni az impériumváltás folyamatát. Felmerül a kérdés, hogy az 1918. október 28-án megalakuló csehszlovák vezetés szándékáról mennyire volt naprakész a város vezetése, és az érsekújváriak mennyire tudhattak arról, hogy a csehszlovák vezetés

13 Magyar Statisztikai Társaság (szerk.): A felvidéki magyarság húsz éve. Budapest: Királyi Magyar Egyetemi Nyomda, 1938, 9. 
terveiben a város is szerepelt. Popély Gyula történész Felvidék 1918-1928 címü könyvében is erőteljesen hangoztatja, hogy a szlovákiai magyarságot teljesen váratlanul és felkészületlenül érte a csehszlovák csapatok területszerző szándéka. Ez igaz lehet Pozsony birtokbavétele kapcsán, viszont az azt követő birtokbavételi folyamatról már egyértelmüen naprakész volt a város lakossága. Nyilván Popély Gyula a könyvében megszólaló korabeli írásokra hagyatkozik, illetve Pozsony elfoglalásának a körülményeiből következtet és általánosít (Popély 2014, 6). Az érsekújvári polgármesternek címzett táviratokból azonban kiderült, hogy a megye ispánja már az őszirózsás forradalmat követően felhívta a figyelmet arra, hogy az ország integritása szempontjából elengedhetetlen a közbiztonság fenntartása (OANZ, Nú 11850/18; OANZ, NÚ 11953/1918).

A közellátási és gazdasági nehézségekkel párhuzamosan a háború végén a hátországi eseményekre kihatással volt az ország feszült belpolitikai helyzete, valamint a vesztes háború esetlegessége. Míg az 1918. év nyarán viszonylag nyugodt volt a közhangulat a városban és környékén, októberben és novemberben a helyzet radikális fordulatot vett. A közellátási zavarok, a kilátástalan gazdasági helyzet, valamint a frontvonalakról hazatérő katonák újabb konfliktusok gócpontjai lettek.

Pozsony megye alispánja szerint a rablási és rombolási vágy annyira erőt vett az embereken, hogy rabolt és rombolt nemcsak a csöcselék, de megtette a szabadságon lévő katona, a napszámos, néhol pedig a legmódosabb gazda. ${ }^{14} \mathrm{~A}$ támadások áldozatai leginkább a zsidók, a hatóságok és a módosabb családok voltak. A különböző harcterekröl hazajövő katonákból alakult rablóbandák a közbiztonságot teljesen felforgatták, s ez az ellenük fellépő csendőrség helyi erőit teljesen kimerítette. Az egyik leghíresebb, Prokopec Ferenc és Virág Ferenc vezetése alatt müködő, közel 70 föből álló rablóbanda Érsekújvártól kiindulva mintegy ötven km-es távolságban fosztogatott.

A háború utolsó éve teljesen kimerítette a hátországot. Az 1918-ban egyre érezhetőbb gazdasági és élelmezési nehézségeket megszorításokkal és különböző juttatásokkal próbáltak orvosolni. A belső kohézió stabilizálása érdekében a közbiztonság fenntartása volt a legföbb cél, hogy az ország integritása megmaradhasson. Ezt a tendenciát mutatták a föhatalom elképzelései is. Ebből a szempontból csak annyit jegyezhetünk meg, hogy az itt élő magyarságot nem érhette teljesen váratlanul a csehszlovákok szándéka, hiszen az érsekújvári városi vezetésben történő közbiztonsági intézkedések szigorításai arra utalnak, hogy a városi vezetés közvetlenül 1918 októbere után még mindig úgy vélte, hogy a közbiztonság az esetleges cseh területszerző igényekre is megoldás lehet.

A közbiztonság javitásánakazigényét Haiczl Kálmán szőgyéni plébános Egyháztörténelmi emlékek a cseh megszállás korából címü emlékiratában is megörökítette: „azokban a zürzavaros időkben, 1918. év őszén, amikor »kitört a szabadság“, mely a hazatért katonaság szabad lövöldözéseiben, a vasúti kocsik ablakainak beverésében és minden elpusztítható felszereléseinek tönkretételében, majd a szabadság "szent“ nevében a boltok, elsősorban természetesen a zsidó boltok kirablásában nyilvánult meg, a nagy fejetlenség láttára sem igen gondoltunk arra, hogy e szabadság az ország romlására és erőszakos felosztására fog vezetni” (Haiczl 1940, 10).

14 Alispáni jelentés. Pozsony vármegye Hivatalos Lapja, 1918. november 15., külön lenyomat. 
Emellett a magyarországi nemzetiségek elszakadási igényéröl már 1918 júniusában tudni lehetett, s csak annak a mérete volt kérdéses. Vagyis nem lehetett tudni, hogy az újonnan alakuló állam déli határai hol húzódnak majd. A Nyugatmagyarországi Híradó szerint a nemzetiségek és a pacifisták fogyó türelme egy együttes veszély forrása lehetett: „ellenségeink befolyásolják a közvéleményünket, lazítják nemzetiségeinket. Nem szabad türni, hogy e nagyon is céltudatos rókák mellé a demokrácia jelszavát bőgő különösen jámbor birkák álljanak. A legmélységesebb demokratának nem lehetnek közösek a céljai a fizetett entente ügynökökkel. Emez áruló, amaz még a legrosszabb esetben is csak fantaszta, kettőjük között közösség nem létezik." (Idézi Filep 2010, 28)

Jankovics Marcell író a könyvében például egy Semmeringbe tett látogatása során hallott elöször arról, hogy az antantnak szándékában áll Magyarországot feldarabolni (Jankovics é.n. 11; Filep 2010, 29). Jankovics mellett Szüllö Gézának is idő előtt tudomására jutott, hogy Csehszlovákia megalakulása napirendre került: „1918 szeptemberében mutatkoztak az első nyugtalanító jelenségek. Beszámoló körúton voltam választókerületemben, Bazinban és Modorban. [...] Zoch Sámuel ekkor már tudott arról, hogy a szlovákok szeptember végén értekezletet fognak tartani, de sem előttem, sem a társai előtt nem tett említést semmiröl. [...] Annál nagyobb volt a meglepetésem, amikor szeptember vége felé egyik pártfogoltam, Fábry Pál bizalmasan közölte velem, hogy a nyugati hatalmak már megegyeztek abban, hogy megteremtsék Csehszlovákiát." (Szüllő 1939, 3)

1918. október 28-án megalakult a Csehszlovák Köztársaság. A kormánynak ekkor még nem állt rendelkezésére elegendő katonai erő, és jogkörét is csak fokozatosan tudta alkalmazni az új állam egész területén. A magyarok által lakott vidéken azonban - ahol a lakosok csak a magyar államot ismerték el - ez a szándék nehézségekbe ütközött.

A budapesti forradalmi változások után a Károlyi Mihály vezette Magyar Nemzeti Tanács megalakulásának a felhívására szinte a Felvidék minden településén vidéki nemzeti tanácsok alakultak, ahol próbáltak hatást gyakorolni az egyes régiók igazgatására. Vágovits Gyula visszaemlékezése alapján 1918. november 18-án Érsekújváron, a Kossuth téren a Nemzeti Tanács megalakulásának a hírére hatalmas tömeg előtt mondott beszédet a város polgármestere, Steiner Gyula. Beszédében tájékoztatta a város lakosságát a Tanács megalakulásáról és a veszélyhelyzet súlyosságáról. Külön kiemelte, hogy a szomszédságban élő nemzetiségiek az ország szétszakadását kívánják, s ezért elengedhetetlen, hogy békével megtarthassuk az ország egységét (OANZ, NÚ 1164/1918; Vágovits 1944, 74). Ebböl is kiderült, hogy a magyar integritás megtartását a közbiztonság kialakításában látták, vagyis hogy ha a magyar vezetésnek sikerül a felforgató elemeket kiküszöbölnie, akkor Érsekújvár magyar város maradhat (OANZ, NÚ 1210/1918; OANZ, NÚ 12008/1918).

A kinyilatkoztatás időszerüségét az is jól jelzi, ami 1918. november 14-én történt. Ugyanis összeült az első csehszlovák nemzetgyülés, amelynek megalakítása úgy történt, hogy kooptálás útján 256 személy vált tagjává. A szlovákság úgy képviseltette magát, hogy Vavro Šrobár tejhatalmú minisztert negyven fő megszervezésével bízták meg, így a hozzá közelebb álló személyeket választotta ki, s ez által lettek tagjai a nemzetgyülésnek. A nemzetgyülésbe nem tartoztak bele az államot alkotó 
nemzetiségek, vagyis a szudétanémeteknek, a magyaroknak és a lengyeleknek sem adtak képviseletet. A nemzetgyülés elfogadta első törvényeit, amellyel de facto Érsekújvárt is a Csehszlovák Köztársaság részévé nyilvánították. Megválasztották Tomáš G. Masarykot köztársasági elnökké, Karel Kramářt pedig miniszterelnökké (Popély 2014, 25; Hronský 1976, 168).

Ebben a senki földje állapotban próbált Érsekújvár városa a Csehszlovák Köztársaság elleni mozgalom egyik szereplőjévé válni, azonban csekély eredménnyel. A kedélyeket Magyarország Területvédő Ligájának a közleménye korbácsolta fel: „Tekintettel arra, hogy Magyarország hatóságai mindig jó példával jártak elöl a történelem hasonló nehéz napjaiban, bizalommal fordulunk a Tekintetes Képviselötestülethez [...] hogy munkákat minél erőteljesebb agitációt kifejteni méltóztassék, hogy egész ország száma adjon súlyt müködésünknek." A Liga szándéka szerint felvilágositást kívánt adni minden nemzetiségi polgárnak, illetve a külföldnek. Akképpen érvelt az ország egységben tartása érdekében, hogy a Kárpátokon belüli geopolitikai és gazdasági egységnek a megbontása lehetetlen (OANZ, NÚ 13110/1919).

A Csehszlovák Nemzeti Bizottság már 1918. november 2-án eldöntötte a déli területek megszállását az antant támogatásával. Így a tüntetésen kívül szükségessé vált a feltétlen lojalitás kérdése. A magyarországi vezetés ezért a városi vezetéstől kérte a hüségesküt (OANZ, NÚ 11665/1919). Annál is égetöbb volt a mozzanat, mivel 1919. január 1-jén Barreca Riccardo a csehszlovák csapatok, illetve az antant haderö élén elfoglalta Pozsonyt (Popély 2014, 27).

A feszült helyzet tovább bonyolódott, amikor az érsekújvári lakosság tudomására jutott, hogy Pozsony elveszett. 1919. január 2-án újra összegyültek a város főterén, ahol Szmrecsányi György, Pozsony vármegye ispánja mondott nagy horderejü beszédet azzal a céllal, hogy megszervezésre kerüljön egy ellenállás a cseh légiók feltartóztatására. Vágovits visszaemlékezése alapján megtudhatjuk, hogy: „Óriási, eddig még alig látott tömeg gyült össze a korai délutáni órákban a város főtéren. Az emelvényröl maga Szmrecsányi kormánybiztos mondott hatalmas lelkesítő hazafias beszédet. Kétségtelen, hogy nagy szónoki tehetségének megvolt a maga morális hatása, mert ezres tömegek torkából hangoztak el kiáltások: Kiverjük a cseheket, nem hagyjuk veszni Újvárt! A beszéd közben egy drámai jelenet játszódott le. Ugyanis a szónoki emelvényre hirtelen felugrott a szónok mellé egy Zsámboki nevezetü vasutas [...] aki nagykabátja alól kihúzott egy kis vörös zászlót, s kiáltotta a népnek, hogy: „E vörös zászló alatt fogjuk győzelmünket kivívni!« De többet nem mondhatott, mert karok nyúltak fel utána lerántották az emelvényröl és ütlegelni kezdték és a tömegböl kihurcolták. Szmrecsányi folytatta tüzes hangú beszédét, majd felhívására a jelenlevők, dacára a nagy hidegnek, hajadon fővel és szivre tett kézzel és égre tett ujjakkal megesküdtek a szabad ég alatt, hogy fegyvert fognak és a csehek ellen mennek. Még aznap este megkezdődött a hivatalos toborzás. A jelenlevőket feljegyezték és másnap részükre fegyvert és töltényeket adtak és beosztották őket a frontra." (Vágovits 1944, 76)

Amikor a csehszlovák hadsereg Pozsony felől közeledett Érsekújvár felé, a Védelmi Bizottság önkénteseket küldött ellenük, akik egy védvonalat alakítottak ki a várostól mintegy 30 km-es távolságra, Vágsellye és Tornóc között. Január 7-ére a hadsereg a torlaszt áttörte, ami nem okozott különösebb nehézséget. Így a hi- 
vatalnokok egy része és a városvetés legfelsőbb szervei, élükön Steiner Gyulával elhagyták a várost, magukkal vitték a városi pénztár készpénzét is. Másnap, 1919. január 8-tól a város a hivatalos vezetők és rendfenntartó szervek nélkül maradt. Virág és rablóbandája Vágovits elmondása szerint magához ragadta a hatalmat. A fötéren gépfegyvereket állítottak fel és rabolni kezdték az üzleteket, föleg a gazdagabb zsidó kereskedők boltjait (Vágovits 1944, 77).

A város helyükön maradt vezetöi tanácskozásra ültek össze, hogy a megüresedett hivatali tisztségeket betöltsék - pl. Kvetán László lett a polgármester -, illetve tudva azt, hogy a közelgő csehszlovák hadsereg Érsekújvár felé fog vonulni, parlamentereket választottak, hogy tárgyalni tudjanak a város átadásáról. Kvetán László a személyi és vagyoni biztonság érdekében az akkor már Tótmegyeren állomásozó csehszlovák hadsereg bevonulását kérte. A várost képviselők - dr. Gúth Jenő ügyész, Lapka Ágoston kávéházi tulajdonos, Schőn Gyula gyárigazgató, Bárdos Imre gyógyszerész és Chmelár Lajos építkezési vállalkozó - Tardoskedd előtt az országúton várták a csehszlovák katonaságot fehér zászlóval. Január 8-án a cseh légiósok mintegy 800 fövel minden ellenállás nélkül bevonultak a városba.15 Megszállták a város középületeit: a városházát, a postát, a vasútállomást és a pénzintézeteket, később elbocsátották a számukra megbízhatatlannak minősülő magyar ajkú postásokat, vasutasokat és állami alkalmazottakat (Vágovits 1944, 77).

A katonaság fö feladata a város közbiztonságának a fenntartása volt. A város elfoglalása két irányból zajlott: Délután Galánta felöl érkezett a városba egy gyalogezred, majd délután egy órakor egy vonaton szállitott katonai alakulat csatlakozott hozzájuk. Később a délután folyamán Nyitra felöl érkeztek még katonai alakulatok. Első feladatuk a város azonnali megszállása volt. Elfoglalták a város kulcspontjait, nevezetesen a vasúti állomást, a közelében lévő kettes számú postahivatalt, a városházát és a távirati irodát. A városi vezetésben különösebb személyi változásról nem tudunk; annyi biztos, hogy a polgármester, Kvetán László maradhatott a székében és a hivatal is folytathatta munkáját. Sőt, Vavro Šrobár 1919. január 26án kelt levelében kérte a város polgármesterét, hogy a város lakossága fegyverrel keljen a csehszlovák haza védelmére. A város vezetősége a levélre a következő választ küldte: „Érsekújvár népe nem hajlandó fegyverbe szállni hazája ellen, és ragaszkodik a magyar állami létünk organikus épségének megvédéséhez, hazafias, gazdasági és szociális okokból merített meggyőződésből." (Strba 2017, 68)

Ám a katonai jelenléttel egyetemben az új államhoz való tartozás annyit jelentett, hogy nem kerültek kifizetésre a gazdasági és háborús pótlékok. Ez pedig a vasutasok sztrájkjához vezetett. A sztrájk kezdetén 1919. február 3-án 15 órakor megállították a toronyórát. A vasút vezetőségének a figyelmeztetése ellenére nem vették fel a munkát. Ez azzal a fenyegetéssel járt, hogy a magyar nemzetiségü dolgozókat elbocsátják és kiutasítják az országból. Gyakorlatilag a veszély nem volt alaptalan. 750 vasúti alkalmazottat bocsátottak el az állásából, helyükre az osztrák tartományokból elmenekült cseh nemzetiségü alkalmazottak százai igyekeztek elfoglalni a megüresedett helyeket (OANZ, NÚ 2136/1919; Haverla 1986, 56). A vasutassztrájk mérlege még kutatásra szorul, de minden bizonnyal elmondható, hogy ez a kétnapos, Érsekújvárból induló sztrájk később az ország egész területére

15 Érsekújvár és vidéke. 1919. január 12., 1. 
kiterjedt. Az itt megfogalmazott memorandum szövege hatással volt más, magyarok által lakott területek vasúti csomópontjain dolgozókra is. Az 1919. február 4-én megfogalmazott memorandumban a vasúton és a postán dolgozók a következő okok miatt függesztették fel a munkáikat:

1. „[Követeljük] a köztársaság kormánya által a magyar állami vasutak és a magyar posta alkalmazottainak elöirányzott fizetés kifizetését.

2. Annak érdekében, hogy a hivatásunknak megfelelő szolgáltatást nyújthassuk, követeljük az idegen személyek (cseh hadsereg és a cseh hivatalnokok) eltávolíását.

3. Követeljük, hogy [a csehszlovákok] ne éreztessék velünk imperialista törekvéseiket, és hagyjanak fel a magyar nyelv eltörlésére irányuló lépéseikkel, mivel tisztán magyarlakta [terület] esetén ennek biztosítása elengedhetetlen.

4. Az eljárás, miszerint magyarázat nélkül ilyen mértékben csökkentik a fizetésünket, a kapitalista célokat szolgálja.

5. Elvárjuk, hogy intelligens, kultúránkhoz méltó emberekhez méltó módon bánjanak velünk, s a jelenlegi helyzetünk jogalapot teremt arra, hogy a világ proletárjaihoz forduljunk segítségért.

6. Legyen garantálva a politikai szabadság és az egyesülési jog olyan módon, ahogyan az a magyar államban müködött, egészen addig, amíg a békekonferencia nem hoz igazságos döntést a területi kérdéseket illetően.

7. Biztosítsák a létfenntartásunkhoz kellő szükségleteket, mint a ruházat, villany és tüzelöanyag, mert ezek hiánya minden eddiginél elviselhetetlenebb súllyal nehezedik ránk.

8. Megmozdulásunk (sztrájkunk) ne ütközzön se személyes, se anyagi korlátozásba.

E pontok teljesülését követöen azonnal folytatjuk a munkát." (VHA Praha, fond WVS, k. 4, 239/pol)

A sztrájk következménye az volt, hogy a szlovák vezetés elrendelte a számára megbízhatatlannak számító magyar nemzetiségű alkalmazottak elbocsátását, s a későbbiekben csak azokat a személyeket alkalmazta - mind a hivatalnoki, mind a közalkalmazotti szférában -, akik leteszik az új államhoz tett hüségesküt; a helyi rendfenntartó szervekre a leszerelés várt. Ráadásul elöbb bevezette az ország déli részére vonatkozó statáriumot, majd 1919. február 14-én a Tejhatalmú Minisztérium Nyitra vármegye területén elrendelte a nép nyelvén való hivatali ügyintézést, azaz hivatalosan csak a csehszlovák nyelvet lehetett használni (Popély 2014, 30). Tavasszal pedig sikerült a városi tanács tagjait is leváltani. Kvetán Lászlót Füzék János váltotta, aki Rózsahegy első helyettes tanácsnoka volt. A várost vezetö közhivatalnokokat sorra egyszerüen leváltották, s helyükbe cseh nemzetiségü hivatalnokokat állítottak. A többi hivatalnokot meghagyták tisztségükben, s tovább folytathatták munkáikat. Az újonnan érkező hivatalnokok egyébként lojálisak maradtak a város lakosságához, s ugyanez forditva is igaz volt. A lakosság egyrészt valószínűleg a rend helyreállitóit látta a cseh vezetésben, másfelől pedig alkalom sem nyilt arra, hogy valamilyen ellenállást szervezzenek. Így tehát az érsekújvári lakosság - látszólag közömbösen - kezdett lassan beletörödni az új helyzetbe, amit az is bizonyít, 
hogy a város gazdasági élete újra kezdett müködni most már cseh uralom alatt. Ez az állapot nem volt hosszú életü, ugyanis a Tanácsköztársaság 1919. március 21es kikiáltásától kezdve egy új fejezet kezdődött a város történetében.

\section{Összegzés}

A dolgozat az impériumváltás első felvonását szerette volna bemutatni az Érsekújvárban történt események tárgyalásában. Már Csehszlovákia 1918. október 28-án történő kikiáltása után sejteni lehetett, hogy az egykori Monarchia északi területein egy új állam van születőben, annak határait és nagyságát azonban még „,senki sem sejthette". Mindazonáltal Pozsony 1919. január eleji elfoglalása jelezte, hogy a város a magyar integritás szempontjából nincs biztonságban. Ennek érdekében Érsekújvárban több olyan intézkedés született, amely azt szerette volna kifejezni, hogy a várost nem kivánják Csehszlovákia részévé tenni. Arra a kérdésre tehát, hogy a szlovákiai magyarságot mennyire érte váratlanul és felkészületlenül az impériumváltás, felemás választ adhatunk. Pozsony elfoglalásáig valóban nem sejthette a helyi és a magyarok által lakott területek lakossága, hogy ő is érintett lehet és az anyaországon kívülre kerülhet, azonban az azt követő időszakban már nem mondhatjuk azt, hogy váratlanul érte volna a szlovákiai magyarságot a csehek területszerző szándéka. Az, hogy erre mennyire lehetett felkészülni, már egy másik kérdés, amelyben Popély Gyulának és Simon Attilának adhatunk igazat, miszerint valóban felkészületlenek voltak.

Az impériumváltás bekövetkeztének köszönhetően az addig ezen a területen élő magyarság kulturális és politikai fölénye fokozatosan visszaesett, s ezt nem csupán számbeli alárendeltsége okozta, hanem azok a negatív, tendenciózus népesedési mutatók is, amelyek végigkísérték a két háború közötti időszakot. Emellett az elönytelen pozíciójára vonatkozóan megállapithatjuk, hogy a hivatalnoki réteg eltünésével kiesett az a nagyszámú középréteg, amely az átállás során betölthette volna a közösséget összekötő szerepet az etnikum amúgy is körülményes területi elhelyezkedésének ellenére. Végül a közösség gazdasági és szociális helyzete is alakitotta a szlovákiai magyarság lépéslemaradását a csehszlovák többségi nemzethez képest. Az impériumváltás első lépéseként létrejövő cseh megszállást a civil lakosság neutrálisan tudta kezelni, legalábbis Érsekújvárban. Ennek oka, hogy a nemzeti érzelmeket valószínüleg felülírta a közbiztonság fenntartásának a vágya, illetve az is sejthető, hogy a lakosság mindezt átmeneti állapotként élte meg. 


\section{Irodalom}

A magyar szent korona országainak népszámlálása (1912): Budapest.

Ablonczy Balázs (2018): Menni vagy maradni? Az 1918 utáni távozás és a helyben maradás motívumai az emlékiratokban. Pro Minoritate, 2018/4.

Alispáni jelentés. Pozsony vármegye Hivatalos Lapja, 1918. november 15., külön lenyomat. Angyal Béla (2002): Érdekvédelem és önszerveződés. Fejezetek a csehszlovákiai magyar pártpolitika történetéből 1918-1938. Galánta-Dunaszerdahely: Fórum Kisebbségkutató Intézet - Lilium Aurum.

Bárdi Nándor - Fedinec Csilla - Szarka László (szerk.) (2008): Kisebbségi magyar közösségek a 20. században. Budapest: Gondolat Kiadó.

Bukovszky, László (2005): Államhatalmi változások a Mátyusföldön 1918-1919-ben és 1938-ban. In: Mátyusföld II. Egy régió története a XI. századtól 1945-ig. Komárom-Dunaszerdahely: Forum Kisebbségkutató Intézet - Lilium Aurum.

Deák, Ladislav (1995): Slovensko a Mad’arsko v rokoch 1918-1920. Martin: Matica Slovenská.

Érsekújvár és vidéke, 1919. január 12., 1.

Filep Tamás Gusztáv (2011): Főhatalomváltás Pozsonyban, 1918-1920. Budapest: Kalligram.

Haiczl Kálmán (1940): Egyháztörténelmi emlékek a cseh megszállás korából. Esztergom. Haverla, Miroslav (1986): A sztrájkmozgalom kezdetei Nové Zámky környékén (19041938). Érsekújvár: Castrum novum, Járási Múzeum évkönyve 3.

Houdek, Fedor (1931): Vznik Hraníc Slovenska. Bratislava: Nákl. Prúdov.

Hronský, Marián (1976): Slovensko na rázcestí. Košice.

Hronský, Marián (1987): Slovensko pri zrode Československa. Bratislava: Pravda.

Jankovics Marcell (2010): Húsz esztendő Pozsonyban. Somorja: Mery Ratio (eredeti: 1939).

Jászi Oszkár (1982): A Habsburg Monarchia felbomlása. Budapest: Gondolat Kiadó.

Ježek, Zdeněk (1928): Boj o Slovensko v letech 1918-1919. Praha: Vlastní náklad.

Jócsik Lajos (é. n.): Idegen igában. Budapest: Athenaeum.

Jócsik Lajos (é. n.): Iskola a magyarságra. Egy nemzedék élete húsz éves kisebbségben. (h. n.): Nyugat.

Magyar Statisztikai Társaság (szerk.) (1938): A felvidéki magyarság húsz éve. Budapest: Királyi Magyar Egyetemi Nyomda.

Medvecký, Karol (1931): Slovenský Prevrat. III. Trnava: Spolok Sv. Vojtecha.

Michela, Miroslav (2009): Pod heslom integrity. Bratislava: Kalligram.

Mráz, Josef: O předběžném sčítání lidu na Slovensku roku 1919. I. Československý statistický věstnik.

OANZ, NÚ (Okresný archív Nové Zámky Notársky úrad) 1164/1918

OANZ, NÚ 11665/1919

OANZ, NÚ 11850/18

OANZ, NÚ 11953/1918 
OANZ, NÚ 12008/1918

OANZ, NÚ 1210/1918

OANZ, NÚ 13110/1919

OANZ, NÚ 2136/1919

Ölvedi János: A szlovenszkói magyarság társadalmi rajza. Magyar Î́rás, 1926/3., 1.

Popély Gyula (1990): A felvidéki sorsforduló. Etnikum, impériumváltás, országhatár. Regio, 1990/1-2.

Popély Gyula (1995): Ellenszélben. A felvidéki magyar kisebbség első évei a Csehszlovák Köztársaságban (1918-1925). Pozsony: Kalligram.

Popély Gyula (2010): Felvidék 1914-1920. Budapest: Magyar Napló.

Popély Gyula (2014): Felvidék 1918-1928. Az első évtized csehszlovák uralom alatt. Budapest: Kárpátia Stúdió.

Popély Gyula (1991): Népfogyatkozás. A csehszlovákiai magyarság a népszámlálások tükrében 1918-1945. Budapest: Regio.

Romsics Ignác (2018): A nagy háború és az 1918-1919-es magyarországi forradalmak. Budapest: Helikon.

Romsics Ignác (2001): A trianoni békeszerződés. Budapest: Osiris Kiadó.

Romsics Ignác (2017): Magyarország története. Budapest: Kossuth Kiadó.

Sčitání lidu v republice Československé ze dne 1. prosince 1930. Státní úrad statistický, Praha 1934.

Sčítání lidu v republice Československé ze dne 15. února 1921. I. Štátní úřad statistický, Praha 1924.

Seznam miest na Slovensku podl'a popisu l'udu z roku 1919. Bratislava.

Simon Attila (2019): Csehszlovákiai diplomáciai iratok a magyar-szlovák államhatár kijelöléséhez (1918-1920). Budapest: MTA-BTK-TTI.

Simon Attila (2017): Kassa három megszállása. Párhuzamok és tanulságok. Történelmi Szemle, 2017/4.

Simon Attila (2010): Egy rövid esztendő krónikája. A szlovákiai magyarok 1938-ban. Somorja: Fórum Kisebbségkutató Intézet.

Strba Sándor (2017): Érsekújvár II. Érsekújvár: Magánkiadás.

Szekfü Gyula (1920): Három nemzedék. Budapest.

Szemle. Nyugatmagyarországi Hiradó, 1918. június 23., 2.

Szlovákiai Magyar Adatbank: Településtár. http://telepulesek.adatbank.sk/

Szomolányi, Anton (1931): Prevrat na južnom Slovensku: 1918-1919. Lovasovce.

Szüllö Géza (1939): Húsz magyar esztendö. Visszaemlékezéseim az elszakított Felvidék küzdelmeire. Pesti Hírlap, 1939. február 12., 3.

Turczel Lajos (2007): Két kor mezsgyéjén. Pozsony: Madách-Posonium.

VHA Praha, fond WVS, k. 4, 239/pol

Vágovits Gyula (1944): Historia. Érsekújvár.

Zeidler Miklós (szerk.) (2003): Trianon. Budapest: Osiris Kiadó. 